\title{
Rehabilitation of Drug Addicts at the at-Taubah Islamic Boarding School for Drug Rehabilitation in Pelawan Jaya Village, Sarolangun, Jambi, Sumatra
}

\author{
$1^{\text {st }}$ Handika Riyadi $^{1}, 2^{\text {nd }}$ Abdullah Yunus ${ }^{2}, 3^{\text {rd }}$ Massuhartono $^{3}, 4^{\text {th }}$ Sandi Maspika ${ }^{4}$ \\ \{ handikar@gmail.com ${ }^{1}$, abdullahyunus@uinjambi.ac.id ${ }^{2}$, massuhartono@uinjamabi.ac.id ${ }^{3}$, \\ sandimaspika@yahoo.com $\left.{ }^{4}\right\}$
}

UIN Sulthan Thaha Saifuddin Jambi ${ }^{1,2,3,4}$

\begin{abstract}
The purpose of this research is to examine the phenomenon that occurs in the At-Taubah Narcotics Rehabilitation Islamic Boarding School in Pelawan Jaya Village, Pelawan District, Sarolangun Regency. Researchers observe and collect information on the drug addicts rehabilitation process at At-Taubah Narcotics Rehabilitation Islamic Boarding School, and find out all the rehabilitation activities on patients and students there. Researchers received information from the Head of the Pondok and teachers or Ustadz-Ustadzah and several students. Data were collected through observation, interviews, and documentation with data analysis techniques through reduction, data review, and data verification. The authors found the advantages and disadvantages of the method used in dealing with drug addicts who carry out rehabilitation at the At-Taubah Narcotics Rehabilitation Islamic Boarding School. Over time, many interesting things are seen in the rehabilitation process carried out by drug addicts.
\end{abstract}

Keywords: Drug addicts rehabilitation, boarding school, rehabilitation.

\section{Introduction}

The development of drug abuse and illicit trafficking has become a world problem that does not recognize regional and state boundaries and has become a global problem that threatens almost all aspects of people's lives, nations, and countries. The impact caused as a result of the illicit trafficking of drug abuse is proven to be very detrimental which can be viewed from all aspects such as medical, social, legal, economic, and security. Even if there is no effective and sustainable prevention, it can cause the nation to lose its generation[1].

The World Drugs Report 2018 published by the United Nations Office on Drugs and Crime (UNODC), states that as many as 275 million people in the world or $5.6 \%$ of the world's population (aged 15-64 years) have used drugs. Meanwhile in Indonesia, BNN as the focal point in the field of prevention and eradication of drug abuse and illicit trafficking pocketed the drug abuse rate in 2017 as many as 3,376,115 people in the age range of 10-59 years. Meanwhile, the number of drug abuse among students in 2018 (from 13 provincial capitals in Indonesia) reached 2.29 million people. One group of people who are prone to be exposed to drug abuse are those who are in the age range of 15-35 years or the millennial generation[2].

Drugs are derived from the abbreviation of the word NAPZA which means Narcotics, Psychotropics, and other Addictive Substances where drugs themselves are chemicals that work to affect the work of the central nervous system which can relieve pain and cause stupor (klenger) and which can cause decreased or altered consciousness, loss of consciousness taste, reduce to eliminate pain, and can cause dependence. In the last three years, the City of Jambi has experienced ups and downs in the number of narcotics users. In a survey in 2017, 82 people reported themselves to the Jambi City National Narcotics Agency (BNN). The prevalence itself is a survey of the population aged 10-59 years 
divided by the level of drug abuse. Meanwhile, from the year it was discovered that drug users reported themselves to the National Narcotics Agency of Jambi City as many as 75 people in 2018. The circulation of narcotics in Indonesia, especially in Jambi, comes from China. with the type of methamphetamine that became the first circulation. Based on the results of the disclosure of narcotics crime cases by the National Narcotics Agency (BNN) of Jambi City, the number of drug abusers in 2019 in Jambi was 95 people and increased from the previous year[3].

The role of rehabilitation in healing addiction for narcotics addicts is very important, because of the increasing number of narcotics addicts among children to adolescents. The effectiveness of rehabilitation to cure victims of narcotics is very necessary, considering the difficulty of victims or narcotics users to be able to be separated from drug dependence individually. Users or addicts of narcotics on the one hand are perpetrators of criminal acts, but on the other hand, are victims. Appropriate crime prevention efforts should not only focus on various matters relating to the causes of crime but on what methods are effectively used in crime prevention. Providing rehabilitation for narcotics abusers is considered necessary to suppress the use of narcotics and illegal drugs[4].

The drug rehabilitation carried out at the Islamic boarding school is unique. Before carrying out the rehabilitation process, patients who want treatment must bring 500 thousand rupiahs and the money is not for personal use but for the cost of staying at the lodge for 3 days. The practice carried out during the rehabilitation process is very unique and can be said to be great because the patient's rehabilitation period is only 3 days and it can be said to be cured or free from drug addiction.

\section{Methodology}

To explain the object of this research, the researcher uses field research. The type of research used to determine the drug rehabilitation process in a drug rehabilitation Islamic boarding school in Pelawan Jaya Village, Pelawan District, Sarolangun Regency is a qualitative research type. This research uses the purposive sampling technique. Collecting data in the form of observation, interviews, and documentation using data analysis techniques, namely data reduction, data review, and data verification.

\section{Result and Discussion}

\subsection{The Rehabilitation Process for Drug Addicts}

The term rehabilitation in the psychological dictionary is the restoration of repair, restoration to normality, or recovery to the most satisfactory status for individuals who have suffered from a mental illness. Whereas in the counseling dictionary, rehabilitation is a process or program of mastering mental health or lost abilities that are patterned to correct the results of emotional problems and restore lost abilities.

In this case, the procedures before carrying out the rehabilitation of drug addicts are very necessary so that later there will be no obstacles or complaints, both from students who are being rehabilitated or from those who rehabilitate during the rehabilitation process. The initial steps or initial procedures before carrying out rehabilitation for drug addicts at the At-Taubah Pelawan Jaya drug rehabilitation boarding school are as follows:

1. There is approval from the santri's family, the family in this case plays an important role in the smooth operation of the rehabilitation process. The role of the family here is said by Ustadz Ahmad as a rehabilitation counselor.

2. Paying an administrative fee that is designated as the cost of eating and drinking for the patient along with the patient's cigarette, amounting to 500 thousand rupiahs during the 
rehabilitation process at the At-Taubah Pelawan Jaya drug rehabilitation boarding school.

3. It is forbidden to leave the boarding school area during the rehabilitation process.

4. It is not allowed to bring cellphones during the rehabilitation process.

5. It is forbidden to bring sedative pills and the like.

6. It is forbidden to receive guests without permission, be it family or friends.

7. The strong intention of the student.

At-Taubah's drug rehabilitation boarding school, from the word pesantren, we already know that the treatment at this boarding school is Islamic methods. By doing early approaches to the patient we do not know the level of withdrawal or how much drug he has used. It is not easy for ordinary people to do this. However, Mr. Ahmad Nursalam with a strong belief in dealing with a disabled patient alone. Such an approach is what Mr. Ahmad does in dealing with every patient who comes. There are several types of evaluation approaches as follows:

\section{a. Experimental Approach}

The experimental approach is an evaluation oriented to the use of experimental science in the evaluation program. This approach is derived from experimental control which is usually carried out in academic research. The purpose of the evaluator is to obtain general conclusions about the impact of a particular program that controls as many factors as possible and isolates the effect of the program. Evaluators try their best to use the scientific method as much as possible.

\section{b. Goal-Oriented Approach}

This approach uses program objectives as criteria to determine success. Evaluators try to measure to what extent the goals can be achieved. This approach is a reasonable and practical approach to program design and development.

\section{c. Decision Focused Approach}

This evaluation approach emphasizes the role of systematic information for program managers in carrying out their duties. Information is useful and helps program managers make decisions. The evaluator needs two pieces of information from the client. First, the evaluator must know the important decisions at each period during the program. Second, the evaluator must know the items of information that may be very influential for each decision.

\section{d. User-Oriented Approach}

In this approach, the evaluator recognizes that there are elements that will affect the usefulness of the evaluation. This element includes approaches, sensitivity, and condition factors. Evaluators involve important people in the evaluation process so that they feel familiar with the evaluation results when presented to them. The advantage of this approach is its attention to the individual dealing with the program and its attention to information that is useful to that individual.

\section{e. Responsive Approach}

A responsive approach is an evaluation that looks for issues from the point of view of people who are involved, interested, and interested in the program. In this approach, evaluators do not believe that answers can be found through tests, questionnaires or analyzes, or statistics. The evaluator's goal is to try to understand each program's business 
from different perspectives. This approach is characterized by qualitative, naturalistic, not quantitative research characteristics.

\section{f. Goal Free Evaluation Approach}

This evaluation approach is an evaluation approach regarding the actual impact and objectivity to be achieved by a program. Evaluators should not know the goals that a program is trying to achieve. This is due to determining the actual effect of program operations. The characteristics of this approach are:

1) Evaluators deliberately avoid knowing the program's objectives.

2) The objectives that have been formulated beforehand are not justified in narrowing the focus of the evaluation.

3) The relationship between evaluators and managers or with project employees is kept to a minimum.

4) Evaluation increases the likelihood of finding unexpected impacts.

At the evaluation stage, Ustadz Ahmad Nursalam used the Product evaluation model. Product evaluation to answer the question, is the program a success? The purpose of product evaluation seeks to identify and access outputs and benefits, both planned and unplanned and short and long term. At-Taubah's drug rehabilitation boarding school is an alternative in healing for drug addicts so that Islamic values are strong in the therapeutic process used by Ustadz Ahmad. The healing process for drug addicts becomes the identity of this therapy so that in its implementation it can be understood according to the explanation from Ustadz Ahmad Nursalam.

It can be understood that Islamic values in therapy applied at the At-Taubah drug rehabilitation boarding school are the basis for implementing rehabilitation programs for drug addicts. The rehabilitation program carried out at the At-Taubah drug rehabilitation boarding school through the therapies used has the aim of healing physically and mentally, so that the therapies used to become a program for physical and mental healing for drug addicts.

The existence of rehab students at the At-Taubah Ponpes drug rehabilitation as a healing effort for drug addicts using Islamic therapy, besides the Islamic method used is also the main attraction in the rehabilitation process. The existence of students in rehab is also supported by their desire to recover from drug addiction and also to deepen the religion of Islam. In accordance with the statement of one of the students from Ustadz Ahmad who has been released from drug addiction.

In the evaluation of the At-Taubah drug addict rehabilitation program, Ustadz Ahmad Nursalam evaluates drug addict students who have gone through rehabilitation with various forms of evaluation, sometimes by cell phone for students who are far from the hut and can also come directly to the students. whose residence is not too far from the cottage.

The achievement of therapy carried out by Ustadz Ahmad can be seen from the physical and mental healing of the students, this is following the objectives of the program implemented at the At-Taubah drug rehabilitation boarding school. The indicator of the success of the rehabilitation program at the Islamic Boarding School in healing physically and mentally has been explained by Deni Kurnia as General Secretary at At-Taubah's Drug Rehabilitation Islamic Boarding School.

The success of the rehabilitation program at the At-Taubah Ponpes drug rehabilitation can also be seen when students return to their social life. The physical and spiritual healing that has been felt by the students during the rehabilitation process has always received direct attention by Ustadz Ahmad and also other administrators, where these changes must also be by living during society.

The main purpose of rehabilitation at the At-Taubah drug rehabilitation boarding school is so that narcotics addicts or other types of drugs who have been dependent on these items after leaving the At-Taubah drug rehabilitation boarding school can recover completely with the methods that have been applied. In this case, the At-Taubah drug 
boarding school also aims for the satri who recovered from here to invite other addicts to rehab at the At-Taubah drug rehabilitation boarding school.

Based on a survey conducted by researchers at the At-Taubah drug rehabilitation boarding school, it is known that many rehab students have recovered and been able to stop using narcotics or drugs with varying degrees of healing, but not for a long time, at most within 1 year. month. To maintain the success of physical and spiritual healing of drugaddicted students, there are several efforts made by the Islamic Boarding School after completing the rehabilitation program through Islamic therapies. One of the efforts made by the Islamic Boarding School was explained directly by Ustadz Ahmad as the Chair of the Islamic Boarding School.

With the provision of students, it is hoped that the alumni of students will be able to return to the family environment and society as a whole. In addition, efforts to communicate with the family carried out by Ponpes are always carried out to maintain good relations with alumni of students and their families. In addition to the intensity of communication between the family and Ponpes, visits to the alumni of santri are also a concern for Ponpes in seeing the success of the therapy program implemented at At-Taubah Ponpes drug rehabilitation.

The success of the therapy program implemented by Ustadz Ahmad at the At-Taubah Drug Rehabilitation Islamic Boarding School can be felt by students when they are at the Islamic Boarding School or when they return to their families. This success can be seen in the physical and spiritual health of students and the success of students in living a social life without drugs. This success is always maintained through a communicative relationship between Ponpes and alumni of students and their families.

Motivation is an instinctive drive in every individual. A person's level of motivation varies depending on his goals and drive for change. In general, motivation is constructive and provides direction to act systematically. People who are addicted to drugs, of course, need motivation, knowledge, expertise, and also high enough patience in dealing with drug addicts.

But the problem of recovering or not, the drug problem is not a disease, but a behavior. Actually, it all depends on one's intentions and healing drug addicts themselves can be done in various and different ways, such as using da'wah spirituality, religion, and love. The role of the individual in overcoming dependence in drug use is not enough just to be intentional, but high motivation will also be very helpful to get out of dependence on drugs.

1. The supporting factors in the rehabilitation process for drug addicts are as follows:

\section{a. Family Role}

The role of the family in the rehabilitation process for drug addicts is very influential on drug addicts. Family support for drug addicts is a very good action because the patient gets high support and it can have a big impact on the patient in the healing process.

Family support is very important for drug addicts, not only motivation for themselves, but family can also be my assistant in carrying out the rehabilitation process, for example, the wife of an addict who tells about the patient's daily life, patient interactions, behavior patients after taking drugs and their families also play an important role after the patient leaves this rehab. But some families are less supportive of our patients, such as families talking about the patient's badness to the crowd, threatening the patient to be expelled, the main thing is that makes the patient's mentally disturbed so that it can cause the patient to take drugs again. In this case, family support is needed in the success of the rehabilitation process for drug addicts. Without family support, it will certainly hamper the recovery period of drug addicts. 


\section{b. Social environment}

The social environment is one of the factors that can affect the recovery period of drug addicts. The social environment that we know includes the family environment, the environment of peers, and neighbors. A drug addict can be involved in drug abuse, of course starting from an environment where they hang out a lot with drug users. Indirectly if they gather in the environment it will affect him in the process of change. The rehabilitation program is an effort made to recover addicts to drug dependence. Rehabilitation is to save victims of abuse from falling further and behavioral and psychological changes can occur.

\section{Rehabilitation Inhibiting Factors}

Of the several supporting factors for the rehabilitation program above, there are several inhibiting factors in the rehabilitation process for drug addicts, namely as follows:

\section{a. Facilities and Place}

The At-Taubah Drug Rehabilitation Islamic Boarding School is a boarding school that was established for more or less only 3 years and it wasn't too long ago. There are so many facilities that do not yet exist in this Islamic boarding school, including rooms or buildings that are appropriate or the same as other rehabilitation places such as at BNN. With facilities and small buildings that are not improvised, Mr. Ahmad Nursalam as the leader of the Islamic boarding school complains a little about the comfort of drug addict patients who want to be rehabilitated.

That slightly hinders the implementation of the rehabilitation here are the rooms for our rehabilitation and places of worship. It can be seen in our rehab room with only half walls and not covering all the rooms, when it rains all is wet, the roof of the building often leaks, the mattress is not that good with mosquitoes, basically it makes rehab patients less comfortable to stay here. So that every night I have to accompany them so that they are comfortable and not add to the burden on their minds.

These factors can be concluded that a comfortable place can also affect the rehabilitation process. This factor does not only have an impact on the patient, but it also harms Pak Ahmad as the leader of the rehabilitation process for drug addicts. In this case, the inhibiting factor stated by Mr. Ahmad is whereas an encouragement in the rehabilitation of drug addicts patients.

\section{b. Lack of Family Support}

During the rehabilitation process, parents' attention and affection are needed so that they feel motivated to quickly realize what they have done so far. Lack of attention from family or parents is one of the obstacles for caregivers in raising awareness.

\section{c. Severe Addict's State}

The implementation of the rehabilitation program will be hampered if drug addicts have a severe illness, both diseases caused by taking drugs or other diseases such as heart disease, diabetes, and others. The physical and spiritual condition of drug addicts greatly affects the process of daily activities in participating in the rehabilitation program.

\section{d. Lack of Human Resources (HR)}

The lack of human resources (HR) that contribute to the implementation of the therapy program at the At-Taubah Drug Rehabilitation Islamic Boarding School is an 
obstacle in carrying out the rehabilitation process. Where this can cause Ustadz Ahmad difficulty in dealing with students/clients who are in their pocket. This is reinforced by the statement of Ustadz Ahmad as the head of the At-Taubah Ponpes drug rehabilitation, "[The] next obstacle here, is that there is still a lack of teams or partners that I believe can help me in dealing with the students who are rehabilitated here". The lack of human resources has an impact on the instability of performance in the program. Where this can be seen from the handling of students who are in a state of shock or unconsciousness.

\subsection{History of At-Taubah Islamic Boarding Schools}

At-Taubah's drug rehabilitation boarding school is located in JI. Lintas Sumatra, Limau Kapas, Pelawan Jaya Village, Pelawan District, Sarolangun Regency, Jambi Province. This boarding school was founded in 2018. The At-Taubah drug rehabilitation boarding school which is located at Jalan Lintas Sumatra Dusun Limau Kapas, Rt. 003, Pelawan Jaya Village, Pelawan District, Sarolangun Regency, Jambi Province. The At-Taubah Drug Rehabilitation Islamic Boarding School is not far from the public highway so it is very easy to find the address, this pesantren is also located between the borders of the Singkut and Pelawan sub-districts, while the distance for the At-Taubah drug rehabilitation Islamic boarding school to Sarolangun City Regency is also not so far that it only takes about 30 minutes

The At-Taubah drug rehabilitation boarding school was formed in 2018 and has not been inaugurated by the District Social Service or the Ministry of Law and Human Rights (HAM). In the beginning, this hut was just an ordinary Koran, such as learning to read the Qur'an, studying hadith, and other religions and those who studied were not only from among children, there were also adults and teenagers, but the number was not as much as from among children.

Ahmad Nursalam or often nicknamed the drug cleric who lives at fairly simple home, not only teaches children the Koran but also becomes a place of consultation for the parents of the children who recite the Koran at Mr. Ahmad's house, and Mr. Ahmad is also believed to be able to give special prayers. in every problem experienced by the person consulted. There are so many cases that Mr. Ahmad found in giving advice or guidance to people who consulted Mr. Ahmad, such as domestic flights, fights because their husbands took drugs, children who like to drink glue, and many other problems.

After becoming a foundation, the development of At-Taubah's drug rehabilitation Islamic boarding school increased and was visited by many people from various regions, such as from Musi Rawas, Bengkulu, Riau, Muara Limon, and especially Sarolangun Regency. The drug rehabilitation boarding school also has an agenda book for visiting guests, which at the time before it was formed as a foundation did not have a guest log book that came to the boarding school.

At-Taubah's drug rehabilitation boarding school not only provides services for drug addicts but also provides treatment facilities such as Cupping, Therapy, Ruqyah, and others. With the addition of such therapeutic practices, it can also help Ustadz Ahmad in introducing the foundation he founded to students from the practice of cupping, therapy, and ruqyah. The treatment is open only on Wednesdays and Sundays.

Ustadz Ahmad wants the foundation he founded to be known by many people because his determination in dealing with drug addicts is very strong. The Islamic boarding school founded by Ustadz Ahmad is also often visited by city officials, for example, from the Head of Police, BNN, and even the candidate for Governor of Jambi City has visited the At-Taubah Islamic Boarding School.

The At-Taubah Drug Rehabilitation Islamic Boarding School does not have many rooms or buildings, this cottage only has a few main places with an area of $100 \mathrm{~m}$ long and $60 \mathrm{~m}$ wide. This drug rehabilitation boarding school is located almost on the border between Singkut District and Pelawan District in the south and is very close to the causeway with a distance of approximately $150 \mathrm{~m}$. Ustadz Ahmad Nursalam not only provided 
accommodation for the rehab students but also provided vacant land used for farming for the rehab students.

\section{Conclusion}

The Narcotics Rehabilitation Islamic Boarding School At-Taubah is the only Islamic boarding school in Sarolangun Regency, especially those dealing with drug addicts, and from the results of research that researchers have done that the methods used in dealing with drug addicts patients/students are very scientific and under Islamic law. The method applied at the At-Taubah hut is the monotheistic approach, where every patient is a drug addict. First, it will go through the screening or early assessment stage which is carried out by Ustadz Ahmad himself. This method is the key to entering the subconscious realm of the patient, where initially it will be revealed face-to-face directly, which will then hit the psychological realm of the patient. The hope is that it will reach the patient's subconscious, where at the assessment stage it will be asked the extent of the desire to change, the level of the patient's desire to recover. From that assessment, the patient will be led to the realm of monotheism, which is given an explanation and understanding through the verses of the Qur'an.

Rehabilitation of drug addicts is very important for the benefit of the nation. Because there are so many negative impacts that arise, both from the point of view of the community, family, nation and even have a very bad impact on yourself. At-Taubah's drug rehabilitation boarding school not only provides medical rehabilitation in the form of Islamic therapies, which aim to cleanse the soul, heart, and mindset of rehab patients but Ustadz Ahmad Nursalam also provides social rehabilitation for drug rehabilitation patients. By providing social activities that have a positive impact on rehabilitation patients/students.

The role of the family in the rehabilitation process for drug addicts is very influential on drug addicts. Family support for drug addicts is a very good action because the patient gets high support and it can have a big impact on the patient in the healing process. Likewise with the social environment is one of the factors that can affect the recovery period of drug addicts patients. The social environment that we know includes the family environment, the environment of peers, and neighbors. A drug addict can be involved in drug abuse, of course starting from an environment where they hang out a lot with drug users. Indirectly if they gather in the environment it will affect him in the process of change.

Acknowledgment. Authors thank UIN Sulthan Thaha Saifuddin Jambi for the financial support to present and publish this paper at The First International Conference on Education, Science, Technology, Indonesian and Islamic Studies (ICESTIIS).

\section{References}

[1] E. Rahmadona and H. Agustin, "Faktor Yang Berhubungan Dengan Penyalahgunaan Narkoba di RSJ PROF. HB. SA'ANIN," J. Kesehat. Masy. Andalas, vol. 8, no. 2, p. 61, 2014.

[2] PUSLITDATIN, "Penggunaan Narkotika di Kalangan Remaja Meningkat." https://bnn.go.id/ penggunaan-narkotika-kalangan remajameningkat/\#: :text $=$ Sementara\%2520di $\% 2520$ Indonesia\%252C\%2520BNN\%2520selaku,rentang\%2520usia\%252 010-59\%2520 (accessed Nov. 21, 2021).

[3] S. Cornely, "Upaya Badan Narkotika Nasional (BNN) Dalam Mencegah Peredaran Narkotika di Kota Jambi," in Essay, Jambi: UIN STS JAMBI, 2020, p. 2.

[4] D. Novitasari, "Rehabilitasi Terhadap Anak Korban Penyalahgunaan Narkoba," J. Huk. Khairo Ummah, vol. 12, no. 4, pp. 918-919, 2017. 